\title{
Renal pathology in maternal deaths: An autopsy study
}

\author{
Shruti Chandrakar', Anitha Padmanabhan ${ }^{2, *}$ \\ ${ }^{1}$ Senior Resident, ${ }^{2}$ Assistant Professor, Dept. of Pathology, Lokmanya Tilak Municipal Medical College, Mumbai, \\ Maharashtra, India
}

*Corresponding Author:

Email: shrutichandrakar9388@gmail.com

Received: $7^{\text {th }}$ December, 2017

Accepted: $2^{\text {nd }}$ April, 2018

\begin{abstract}
A spectrum of renal pathology is observed during pregnancy, so our main objective was to study the gross pathology and microscopy of the kidney in cases of maternal death, and to establish a clinico-pathological correlation. This was a crosssectional study of all medical autopsies performed on deaths related to pregnancy at our tertiary care hospital over a period of 7 years. In 166 autopsies, pathology was observed in 42 cases, and the kidneys were unremarkable in 124 cases. The most common renal pathology observed was acute tubular necrosis (22 cases), followed by acute pyelonephritis ( 7 cases), disseminated intravascular coagulation with fibrin thrombi ( 7 cases), diabetic nephropathy ( 3 cases), sickle cell anemia ( 1 case), tuberculosis kidney (1 case), and thrombotic microangiopathy (1 case). Renal pathology was observed in $25.3 \%$ of autopsies performed on maternal death, which contributed to a significant number of maternal mortalities and morbidities. The incidence of acute renal failure was $14.28 \%$ in our study. Apart from obstetric complications (e.g. antepartum hemorrhage, postpartum hemorrhage, pregnancy-induced hypertension), infections (e.g. pyelonephritis) were associated with septicemia, deranged renal function tests, and acute renal failure.
\end{abstract}

Keywords: Autopsy, Maternal Death, Renal Pathology.

\section{Introduction}

Pregnancy is characterized by a myriad of physiological changes in the kidney. Acute kidney injury (AKI) is the abrupt loss of kidney function, which results in the retention of urea and other nitrogenous waste products. The development of AKI during pregnancy follows a bimodal distribution with two peaks: one in the first trimester, caused by infections, and the other in the third trimester, due to late obstetric complications. The causes of AKI in pregnant women are divided into three groups: prerenal, intrarenal, and postrenal. The prerenal causes are more common in the earlier stages of pregnancy, and are secondary to ischemia or sepsis. The intrarenal causes are usually associated with pyelonephritis, renal cortical necrosis, and thrombotic microangiopathy, which are secondary to disseminated intravascular coagulation or diabetic nephropathy. The postrenal causes are secondary to obstruction. ${ }^{1,2}$

The histological changes in acute tubular necrosis vary with the severity of the renal failure. Cellular changes range from individual cell necrosis (with denudation of the basement membrane) to the shedding of both viable and necrotic epithelial cells into the tubular lumen. ${ }^{3}$

Renal infection is the most common serious medical complication of pregnancy and it frequently develops in the second trimester. ${ }^{4}$ On gross observation, acute pyelonephritis shows an enlarged kidney with a bulging cut surface. The cortex is whitish-yellow particularly on the subcapsular surface. The medulla shows characteristic whitish-yellow streaks that correspond to collecting ducts filled with pus. In cases of severe obstruction, the renal parenchyma and the pelvis may be filled with pus, which results in pyonephrosis. Microscopy reveals patchy suppurative inflammation, which produces confluent microabscesses. ${ }^{4}$

Obstetrical disseminated intravascular coagulation (DIC) is associated with various complications of pregnancy, such as peripartum hemorrhage, placental abruption, pre-eclampsia/eclampsia, retained stillbirth, etc. The histopathologic diagnosis of DIC is confirmed by the presence of micro thrombi in more than two organs. ${ }^{2}$

Diabetes in pregnancy can have serious consequences for both the mother and the growing fetus. On microscopy, glomerular basement membrane (GBM) thickening, a diffuse form of mesangial sclerosis manifesting as an increase in mesangial matrix, nodular lesions (sometimes combined with micro aneurysms), hyalinosis, and a capsular drop can be seen as well. ${ }^{5}$

Thrombotic thrombocytopenic purpura (TTP) and hemolytic uremic syndrome (HUS) are rare during pregnancy and the postpartum period. Renal cortical necrosis is a frequent finding in patients who die of HUS. Obstetric complications, such as abruptio placentae, septic abortion, eclamptic toxemia, postpartum hemorrhage, and puerperal sepsis, are the most common causes of renal cortical necrosis $(50 \%-$ $70 \%)^{1,3}$ A gross observation reveals large areas of necrosis along with swelling of the kidney, and a reddish, mottled appearance. On microscopy, the glomeruli may show thickening of the capillary walls. ${ }^{6}$ 
Sickle cell disease (SCD) is associated with both maternal and fetal complications and an increased incidence of perinatal mortality. Renal histologic findings in SCD include congestion of the cortical and glomerular capillaries, mesangial proliferation, papillary necrosis thickening of the GBM, and glomerulosclerosis. ${ }^{7,8}$

The effects of tuberculosis (TB) on pregnancy depend upon various factors, such as the site and extent of the disease, the stage of pregnancy, the presence of concomitant disease, the immune status, and the coexistence of HIV infection. The pulmonary and extrapulmonary forms of TB affect pregnant women in the same way as non-pregnant women., ${ }^{1,2,9}$

Our aim was to study the gross observations and histology of the kidney in detail in pregnancy-related deaths, and correlate them with the clinical presentation and a renal function test (RFT). Our objective was also to evaluate the spectrum of renal disease in pregnancy, to study various causes of acute renal failure in pregnancy, and to study whether renal pathology led to maternal death in any of the patients. An extensive search of the literature revealed that not many autopsy studies have been done on this subject.

\section{Methods}

We studied the gross observations and histopathology of the kidney in 166 autopsies performed on women with pregnancy-related deaths over a period of 7 years from April 2011 to July 2017, and correlated these with clinical findings. In all the autopsies in deaths related to pregnancy, the kidney was preserved in $10 \%$ formalin, and hematoxylin and eosin stained sections were studied. Maternal mortality autopsies (where the medicolegal implications were involved) and unnatural deaths unrelated to pregnancy were excluded from the study. Gross observations and microscopies of all the organs were also studied in detail to ascertain the cause of death. There were no ethical concerns related to this study.

\section{Results}

A total of 42 patients showed renal pathology, while 124 cases had no abnormality in the kidney (Table 1).

The patients were aged between 17 and 40 years, with a median age of 28 years. Ten patients $(23.8 \%)$ presented in the second trimester; $14(33.3 \%)$ in the third trimester; and $18(42.8 \%)$ in the postpartum period. A total of 34 patients $(80.9 \%)$ were multigravida and $8(19.04 \%)$ were primigravida. Acute renal failure with deranged RFTs was noted in 6 patients $(14.28 \%)$. There were 37 patients $(88 \%)$ who died due to indirect causes of maternal mortality (predominantly infections), and 5 patients (12\%) died due to direct causes of maternal death (e.g. placenta abruption, pregnancy-induced hypertension, ruptured ectopic pregnancy).
Of our patients, 22 had acute tubular necrosis; 13 $(59.09 \%)$ presented in the postpartum period, and 7 $(31.8 \%)$ in the third trimester. The majority of these were multigravida $(19 ; 86.36 \%)$. The most common presentation was anuria and oliguria. Blood urea nitrogen and creatinine levels were deranged in 18 patients, 3 of whom were in acute renal failure. Postpartum hemorrhage was associated with 10 patients, and antepartum hemorrhage was seen in 4 . On microscopy, the tubules showed evidence of coagulative necrosis. A few detached cells could be seen in the tubular lumina (Fig. 1).

Table 2 shows the distribution of cases of acute pyelonephritis. On gross observation, the kidneys were swollen with pus-filled areas that could be seen externally (Fig. 2). Microscopy showed patchy suppurative inflammation and multiple confluent micro abscesses.

Table 3 shows the distribution of cases of diabetes mellitus. They presented with polyuria, polyphagia, and electrolyte disturbances. On microscopy, thickened GBM was seen. An increase in the mesangial matrix and uniform thickening of the capillary walls, micro aneurysms, and capsular and hyaline drops were noted.

Table 4 shows the distribution of cases of disseminated intravascular coagulation. At autopsy, petechiae were noted in the gastric mucosa, the intestinal mucosa, and the capsule of the liver. Histology revealed the presence of fibrin thrombi in the renal and pulmonary microvasculature (Fig. 3).

A 28-year-old primigravida, who presented in the third trimester with fever and breathlessness, had coexisting thrombotic microangiopathy (HUS-TTP syndrome). A general examination revealed pallor, icterus, petechial hemorrhages, and ecchymosis all over her body. She had thrombocytopenia with total bilirubin $18.6 \mathrm{mg} / \mathrm{dL}$, direct bilirubin $11.2 \mathrm{mg} / \mathrm{dL}$, AST: 144 U/L, ALT: 88 U/L, LDH: 857 (100-190 U/L), fibrinogen: $150(150-400 \mathrm{mg} / \mathrm{dL})$ and deranged RFT. Grossly, the kidneys were bilaterally enlarged with the cut surface showing the rim of peripheral cortical necrosis (Fig. 4A). The lungs grossly showed consolidation. Microscopy revealed glomeruli capillary thickening, fibrinoid necrosis of the endothelium, and fibrin thrombi in the capillaries and afferent renal arterioles (Fig. 4B, 4C). Thickening of glomerular capillary wall with double contours of the GBM was also seen and was confirmed by silver stains (Fig. 4D).

One patient had sickle cell anemia diagnosed at autopsy. She was a 24-year-old primigravida in the second trimester who had an acute presentation in the form of decreased fetal heart sounds, fever, and jaundice. The hemogram revealed severe anemia and a raised total leucocyte count with a high degree of hemolysis, which is suggestive of hemolytic anemia. She had a deranged RFT and coagulation profile. At autopsy, the kidneys showed the presence of pus flakes and left ventricle hypertrophy. The spleen was atrophic 
and only measured $4 \times 4 \times 2 \mathrm{~cm}$. On microscopy, the kidneys showed the presence of a renal abscess and acute pyelonephritis. The blood vessels of all the organs-such as splenic red pulp, kidney, brain, and pulmonary vasculature-were packed with sickle shaped red blood cells (Fig. 5).

There was one patient with TB of the kidney. The patient was a 31-year-old multigravida who presented with flank pain, suprapubic pain, nocturia, and pyuria on the eighth postpartum day. The autopsy revealed that it was a case of disseminated TB involving the lungs, liver, and kidney. On histology, there were areas of caseous necrosis with epithelioid granulomas and occasional Langhans giant cells.
Table 1: Distribution of various renal pathologies in maternal death

\begin{tabular}{|l|c|}
\hline \multicolumn{1}{|c|}{ Renal Pathology } & No of cases (\%) \\
\hline Acute tubular necrosis & $22(52.3)$ \\
\hline Acute pyelonephritis & $7(16.6)$ \\
\hline $\begin{array}{l}\text { Disseminated intravascular } \\
\text { coagulation }\end{array}$ & $7(16.6)$ \\
\hline Diabetic nephropathy & $3(7.1)$ \\
\hline Sickle cell nephropathy & $1(2.3)$ \\
\hline Thrombotic microangiopathy & $1(2.3)$ \\
\hline Tuberculosis of kidney & $1(2.3)$ \\
\hline Total & $42(100)$ \\
\hline
\end{tabular}

Table 2: Distribution of cases of acute pyelonephritis

\begin{tabular}{|l|c|c|c|c|c|c|c|}
\hline Case no & Age & Parity & Trimester & $\begin{array}{c}\text { Renal } \\
\text { function test }\end{array}$ & $\begin{array}{c}\text { Urine } \\
\text { R/M }\end{array}$ & Clinical Picture & Cause of Death \\
\hline 1 & 35 & Multigravida & $3^{\text {rd }}$ & ARF & Pus cells + & $\begin{array}{c}\text { Fever, dysuria and } \\
\text { oliguria }\end{array}$ & Septicaemia \\
\hline 2 & 19 & Primigravida & $2^{\text {nd }}$ & Deranged & Pus cells + & $\begin{array}{c}\text { Fever, dysuria and } \\
\text { shock }\end{array}$ & Septicemic shock \\
\hline 3 & 26 & Multigravida & $3^{\text {rd }}$ & deranged & Pus cells + & $\begin{array}{c}\text { Fever, dysuria and } \\
\text { breathlessness }\end{array}$ & $\begin{array}{c}\text { Septicaemia with } \\
\text { ARDS }\end{array}$ \\
\hline 4 & 18 & Primigravida & $2^{\text {nd }}$ & Deranged & Pus cells + & $\begin{array}{c}\text { Fever, dysuria and } \\
\text { breathlessness }\end{array}$ & $\begin{array}{c}\text { Septicaemia and } \\
\text { bronchopneumonia }\end{array}$ \\
\hline 5 & 34 & Multigravida & Postpartum & Deranged & Pus cells + & $\begin{array}{c}\text { Fever, dysuria and } \\
\text { oliguria }\end{array}$ & Septicaemia \\
\hline 6 & 38 & Multigravida & $3^{\text {rd }}$ & ARF & Pus cells + & Fever and shock & Septicemic shock \\
\hline 7 & 29 & Multigravida & Postpartum & Deranged & Pus cells + & Fever and oliguria & $\begin{array}{c}\text { Septicaemia and } \\
\text { bronchopneumonia }\end{array}$ \\
\hline
\end{tabular}

Table 3: Distribution of cases of diabetic nephropathy

\begin{tabular}{|l|c|c|c|c|c|c|c|c|}
\hline Case no & Age & Parity & Trimester & $\begin{array}{c}\text { Type 1 or } \\
\text { type 2 } \\
\text { diabetes }\end{array}$ & $\begin{array}{c}\text { Nodular or } \\
\text { diffuse }\end{array}$ & $\begin{array}{c}\text { Random } \\
\text { blood } \\
\text { sugar }\end{array}$ & $\begin{array}{c}\text { Renal } \\
\text { function } \\
\text { test }\end{array}$ & $\begin{array}{c}\text { Significant } \\
\text { gross finding }\end{array}$ \\
\hline 1 & 35 & Multigravida & $3^{\text {rd }}$ & 1 & $\begin{array}{c}\text { Diffuse and } \\
\text { nodular }\end{array}$ & 221 & Deranged & Swollen \\
\hline 2 & 27 & Multigravida & $2^{\text {nd }}$ & 2 & Diffuse & 199 & Deranged & Unremarkable \\
\hline 3 & 19 & Primigravida & $3^{\text {rd }}$ & 2 & Diffuse & 244 & Deranged & Swollen \\
\hline
\end{tabular}

Table 4: Distribution of cases of disseminated intravascular coagulation

\begin{tabular}{|l|c|c|c|c|c|c|}
\hline $\begin{array}{c}\text { Case } \\
\text { no }\end{array}$ & Age & Parity & Trimester & Cause of death & $\begin{array}{c}\text { Coagulation } \\
\text { profile }\end{array}$ & RFT \\
\hline 1 & 23 & Multigravida & $2^{\text {nd }}$ & IUFD & Deranged \\
\hline 2 & 23 & Multigravida & $3^{\text {rd }}$ & $\begin{array}{c}\text { Molar pregnancy } \\
\text { with } \\
\text { thromboembolism }\end{array}$ & $\begin{array}{c}\text { DDIMER 4.6 FDP } \\
9.56 \text { FIBRINOGEN } \\
286\end{array}$ & ARF \\
\hline 3 & 35 & Multigravida & $2^{\text {nd }}$ & IUFD & Fibrinogen 205 & Deranged \\
\hline 4 & 22 & Multigravida & Postpartum & $\begin{array}{c}\text { Septicaemia f/g } \\
\text { bronchopneumonia }\end{array}$ & PT -INR 3.1 & Deranged \\
\hline 5 & 26 & Multigravida & $2^{\text {nd }}$ & $\begin{array}{c}\text { Molar pregnancy } \\
\text { with } \\
\text { thromboembolism }\end{array}$ & FIBRINOGEN 387 & Deranged \\
\hline 6 & 28 & Multigravida & postpartum & $\begin{array}{c}\text { Case of autoimmune } \\
\text { haemolytic anaemia } \\
\text { (Evans syndrome) }\end{array}$ & $\begin{array}{c}\text { DCT /ICT - } \\
\text { positive, retic- 5.6\% } \\
\text { platelet-16000, PT }-\end{array}$ & Deranged \\
INR 3.4
\end{tabular}


Table 5: Mean age of the patients

\begin{tabular}{|l|c|}
\hline Author & $\begin{array}{c}\text { Median age } \\
\text { (years) }\end{array}$ \\
\hline Patel ML et al $*^{[8]}, \mathrm{n}=60$ & 28 \\
\hline Sivakumar et al $*\left[{ }^{[9]}, \mathrm{n}=59\right.$ & 26.5 \\
\hline Goplani KR et al $*[10], \mathrm{n}=70$ & 25.6 \\
\hline Najar MS et al $*{ }^{[11]}, \mathrm{n}=40$ & 25 \\
\hline Mahesh E et al $*[12], \mathrm{n}=165^{[16]}$ & 25 \\
\hline Our study,n $=42$ & 28 \\
\hline
\end{tabular}

*clinical studies
Table 6: Incidence of acute renal failure

\begin{tabular}{|l|c|}
\hline Author & Incidence (\%) \\
\hline Patel ML et al $*[8], \mathrm{n}=60$ & 11.5 \\
\hline Sivakumar et al ${ }^{[9]}, \mathrm{n}=59$ & 4.3 \\
\hline Goplani KR et al ${ }^{*[10]}, \mathrm{n}=70$ & 9.06 \\
\hline Najar MS et al ${ }^{* 11]}, \mathrm{n}=40$ & 7.0 \\
\hline Our study, $\mathrm{n}=42$ & 14.28 \\
\hline
\end{tabular}

*Clinical studies

Table 7: Causes of acute renal failure in pregnancy

\begin{tabular}{|l|c|c|c|c|c|c|}
\hline Author & $\begin{array}{c}\text { Septicaemia } \\
(\boldsymbol{\%})\end{array}$ & $\begin{array}{c}\text { Antepartum } \\
\text { haemorrhage } \\
(\boldsymbol{\%})\end{array}$ & $\begin{array}{c}\text { Postpartum } \\
\text { haemorrhage } \\
(\boldsymbol{\%})\end{array}$ & $\begin{array}{c}\text { Pregnany } \\
\text { induced } \\
\text { hypertension } \\
(\boldsymbol{\%})\end{array}$ & $\begin{array}{c}\text { Disseminated } \\
\text { intravascular } \\
\text { coagulation }(\boldsymbol{\%})\end{array}$ & Miscellaneous \\
\hline $\begin{array}{l}\text { Patel ML et al } *[8], \\
\mathrm{n}=60\end{array}$ & 41.7 & 6.6 & 6.6 & 33.3 & 1.7 & 10.0 \\
\hline $\begin{array}{l}\text { Sivakumar et al } \\
*[9], \mathrm{n}=59\end{array}$ & 47.41 & 8.47 & 10.16 & 30.50 & & 18.64 \\
\hline $\begin{array}{l}\text { Goplani KR et al } \\
*[10], \mathrm{n}=70\end{array}$ & 61.42 & 14.28 & 24.28 & 28.57 & 32.85 & \\
\hline $\begin{array}{l}\text { Najar MS et } \\
\text { al } *[11], \mathrm{n}=40\end{array}$ & 50 & 15 & 5 & 15 & & 15 \\
\hline Our study, $\mathrm{n}=42$ & 33.3 & 16.6 & 16.6 & 16.6 & & 16.6 \\
\hline
\end{tabular}

*clinical studies

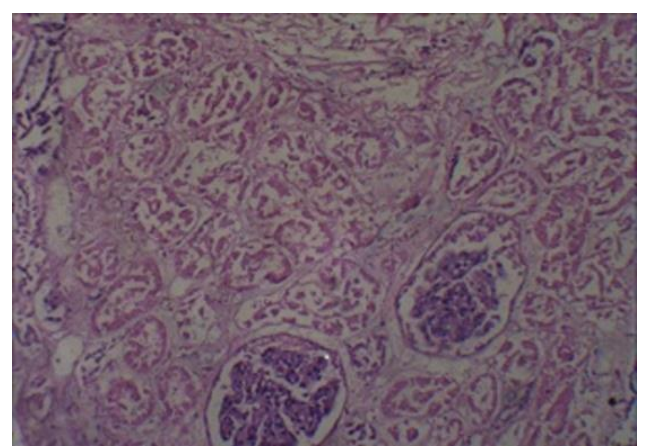

Fig. 1: H \& E $100 \mathrm{X}$ tubules showed evidence of coagulative necrosis. A few detached cells can be seen in tubular lumina

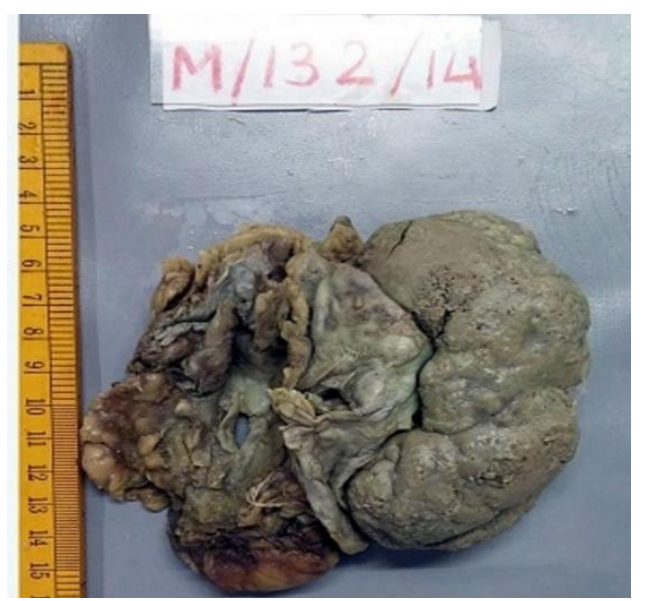

Fig. 2: Kidneys were swollen with pus filled areas seen externally

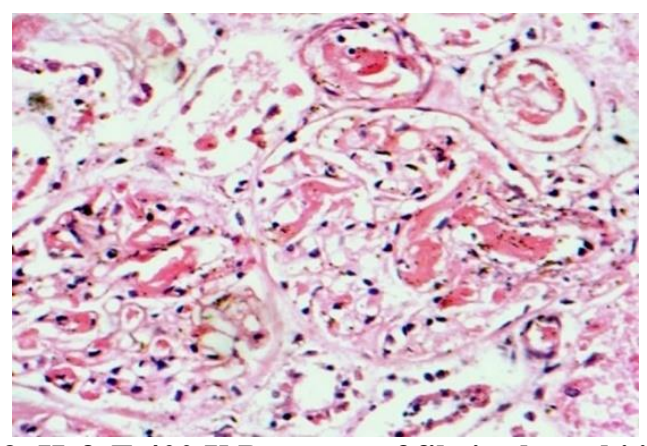

Fig. 3: $\mathrm{H} \& \mathrm{E} 400 \mathrm{X}$ Presence of fibrin thrombi in the renal vasculature 

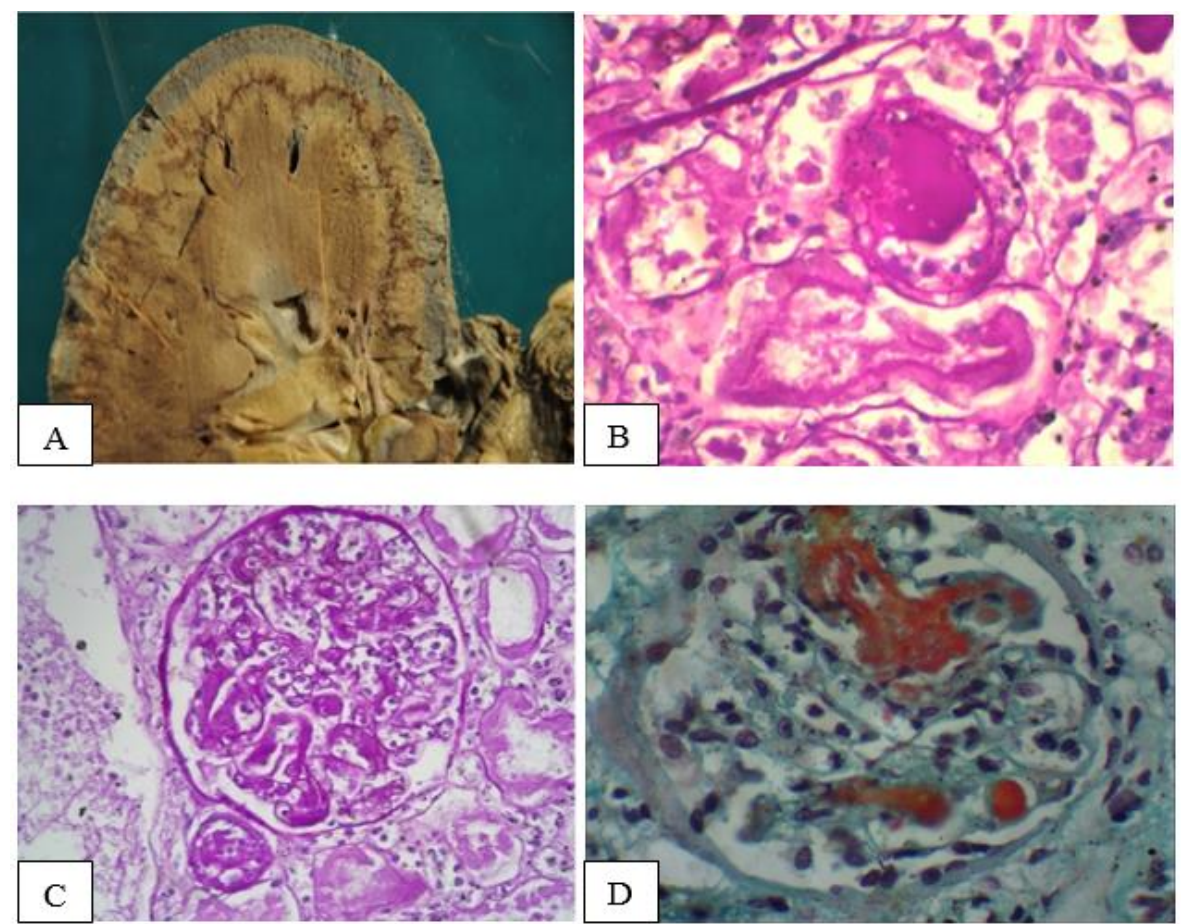

Fig. 4A: Kidneys were bilaterally enlarged with cut surface showing rim of peripheral cortical necrosis; B) and C): PAS $400 \mathrm{X}$ Glomeruli capillary thickening, fibrinoid necrosis of endothelium \& fibrin thrombi in capillaries \& afferent renal arterioles; D): Silver stain thickening of glomerular capillary wall with double contours of the glomerular basement membrane

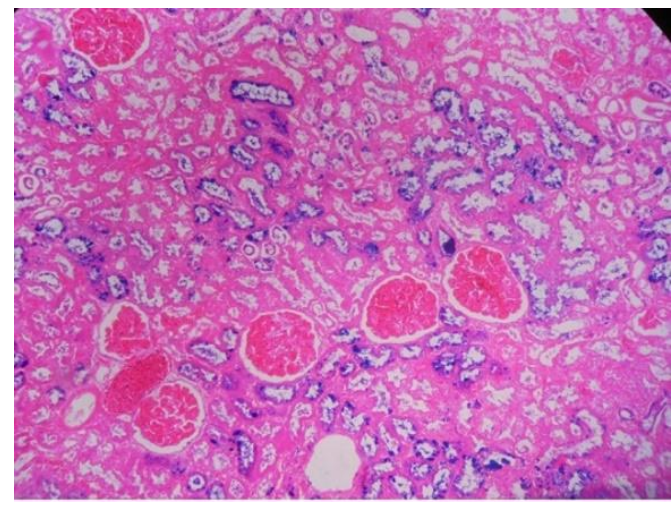

Fig. 5: Prussian blue $100 \mathrm{X}$ - The glomerulus is packed with sickled RBC's and the adjacent tubules show presence of hemosiderin laden pigment

\section{Discussion}

Table 5 shows the mean age of distribution. In our study, we found that the majority of patients $(80.9 \%)$ were multigravida. Patel et al. ${ }^{8}$ found that $46.7 \%$ were multigravida, while Goplani et al. ${ }^{10}$ also observed that $68.57 \%$ were multigravida. In our study, we observed the renal pathology predominantly in the latter half of the pregnancy $(76.1 \%)$, which was similar to the study by Goplani et al., ${ }^{10}$ while Patel et al. ${ }^{8}$ observed renal pathology predominantly in the early part of pregnancy $(53.3 \%)$.

Oliguria and anuria were the most common clinical presentations. Oliguria was observed in $60 \%$ of patients by us, $61.7 \%$ by Patel et al., ${ }^{8}$ and $62.85 \%$ by Goplani et al. ${ }^{10}$

Table 6 shows the incidence of acute renal failure. As shown in Table 7, septicemia was the most common cause of acute renal failure in pregnancy.

Infections, often associated with shock and malignancies, were the most common underlying causes of DIC. ${ }^{11,12}$ In a study of 1,729 consecutive autopsies by Watanabe et al., ${ }^{13}$ the histopathologic diagnosis of DIC - confirmed by the presence of microthrombi in more than two organs-was made in 51 cases. Among them, 38 cases $(74.5 \%)$ were clinically not suspected of having DIC. Sueishi et al. ${ }^{14}$ reviewed the histopathologic characteristics of DIC in autopsy cases and observed that typical hyaline microthrombi preferentially occurred in renal glomeruli.

Faye et al. ${ }^{15}$ studied 70 pregnancies in 58 women with SCD. The average age was 29.3 years. Our patient was a 24-year-old primigravida in the second trimester. Pregnancy in SCD is associated with a high maternal morbidity and stillbirth. Nulliparity, high leukocytes, or a low platelet count were identified as risk factors of fetal loss.

It is believed that TB flares up due to the stress of pregnancy, especially in association with a poor nutritional status, an immuno-deficient state, or coexistent diseases. Also, the loss of protective antibodies in the mother during lactation favors the development of postpartum TB. ${ }^{16}$ 
Fernandes et al. ${ }^{17}$ studied 844 maternal mortality autopsy cases, of which 17 (2\%) had renal cortical necrosis. We observed renal cortical necrosis in only one case $(2.3 \%)$, which was associated with thrombotic microangiopathy.

\section{Conclusions}

Renal pathology was observed in $25.3 \%$ of autopsies performed on maternal death. The incidence of acute renal failure was $14.28 \%$ in our patients. Apart from obstetric complications-such as antepartum hemorrhage, postpartum hemorrhage, and pregnancyinduced hypertension-infections, such as pyelonephritis, were associated with septicemia, deranged RFT, and acute renal failure. Proper and adequate antenatal care, screening for infections, and improving the patient's nutritional status can help to lower the incidence of renal diseases in pregnancy, thereby reducing the maternal mortality rate.

\section{References}

1. Prakash J, Niwas SS, Parekh A, et al. Acute kidney injury in late pregnancy in developing countries. Ren Fail. 2010;32(3):309-13.

2. Dragun K, Haase M. Acute kidney failure during pregnancy and postpartum. In: Jörres A, Ronco C, Kellum J, editors. Management of acute kidney problems. Berlin: Springer; 2010. p. 445-58.

3. Maynard SE, Karumanchi SA, Thadhani R. Hypertension and kidney disease in pregnancy. In: Brenner BM, Rector B, editors. The kidney. 8th ed. Philadelphia: Saunders Elsevier; 2008. p. 1567-95.

4. Hill JB, Sheffield JS, McIntire DD, et al. Acute pyelonephritis in pregnancy. Obstet Gynecol. 2005;105(1):18-23.

5. Kimmerle R, Zass R-P, Cupisti S, et al. Pregnancies in women with diabetic nephropathy: Long-term outcome for mother and child. Diabetologia. 1995;38(2):227-35.

6. Dashe JS, Ramin SM, Cunningham FG: The long-term consequences of thrombotic microangiopathy (thrombotic thrombocytopenic purpura and hemolytic uremic syndrome) in pregnancy. Obstet Gynecol. 1998;91(5):662-8.
7. Beacham WD, Beacham DW. Sickle-cell disease and pregnancy. Am J Obstet Gynecol. 1950;60(6):1217-28.

8. Patel ML, Sachan R, Radheshyam, et al. Acute renal failure in pregnancy: Tertiary centre experience from north Indian population. Niger Med J. 2013;54(3):191-5.

9. Sivakumar V, Sivaramakrishna G, Sainaresh VV, et al. Pregnancy-related acute renal failure: A ten-year experience. Saudi J Kidney Dis Transpl. 2011;22(2):3523.

10. Goplani KR, Shah PR, Gera DN, et al. Pregnancy-related acute renal failure: A single-center experience. Indian $J$ Nephrol. 2008;18(1):17-21.

11. Najar MS, Shah AR, Wani LA, et al. Pregnancy-related acute kidney injury: A single center experience from the Kashmir Valley. Indian J Nephrol. 2008;18(4):159-61.

12. Mahesh E, Puri S, Varma V, et al. Pregnancy-related acute kidney injury: An analysis of 165 cases. Indian $J$ Nephrol. 2017;27(2):113-17.

13. 13.Watanabe T, Imamura T, Nakagaki K, et al. Disseminated intravascular coagulation in autopsy cases. Its incidence and clinicopathologic significance. Pathol Res Pract. 1979;165(3):311-22.

14. Sueishi K, Takeuchi M. Pathology of disseminated intravascular coagulation. Nihon Rinsho. 1993;51(1):306.

15. Faye BF, Kouame KB, Seck M, et al. Challenges in the management of sickle cell disease during pregnancy in Senegal, West Africa. Hematology. 2017;Aug 28:1-4.

16. Good JT, Iseman MD, Davidson PT, et al. Tuberculosis in association with pregnancy. Am J Obstet Gynecol. 1981;140(5):492-8.

17. Fernandes G, Baskaran S, Fernandes E. Renal cortical necrosis at autopsy: A 12-year experience at a tertiary care centre in Mumbai. Int J Med Res Rev. 2017;5(6):626-34.

How to cite this article: Chandrakar S, Padmanabhan A. Renal pathology in maternal deaths: An autopsy study. Ind J Pathol Oncol, 2018;5(3):405-410 